\title{
SOME REFLECTIONS ON THEOLOGY AND POPULAR PIETY: A FRUITFUL OR FRAUGHT RELATIONSHIP? ${ }^{1}$
}

\author{
SALVADOR RYAN \\ St Patrick's College, Maynooth
}

It hardly needs reminding but scholarship over the past twenty years or so has moved quickly to close what was once perceived to be a chasm between so-called 'popular' belief and its 'elite' counterpart. Indeed in recent years historians can be said to have come to a consensus at least on the porous nature of what were once viewed as quite distinct categories. As early as $1978^{2}$ Peter Burke argued that while the 'great' culture of elites remained largely foreign territory to the majority of the population, both the 'little' and the 'great' cultures could be accessed by the higher orders, allowing the nobleman to be pious in a 'popular' sort of way and, indeed, opening up new avenues that permitted traffic to cross categories at least in one direction. Later work by scholars such as Martin Ingram would speak of a 'cultural consensus' uniting all levels and, perhaps most notably, in 1992 Eamon Duffy argued for a degree of religious homogeneity across the social divide by coining the term 'traditional religion'. ${ }^{3}$ In the years since Duffy's The Stripping of the Altars, many scholars, while critiquing his approach, have, nevertheless chosen to join the increasingly long wagon train of academics who like to congratulate themselves on not being associated with their less 'enlightened' predecessors who only viewed the world in black and white - popular or elite religion, non-official or official religion, unlearned or learned religion, heretical or orthodox religion, superstition or sound doctrine. However, while everyone seems now to be an expert on what was wrong with the old system, few are confident about what should replace it. If there are to be categories such as 'popular piety' at all, the challenge now seems to be how they should be defined.

It appears to me that one way of getting around the problem is to define popular religion simply as doctrine responded to and appropriated by people. Whether these people are from lay or clerical backgrounds, learned or unlearned, peasant or noble is not the point: the transition to 'popular' religion occurs when doctrine is received and put into practice. Responses to doctrine may differ; in certain cases they may be skewed and uncertain, lacking intellectual finesse; at other times, they might be deeply insightful or even spiritually moving. Historical studies have shown to great effect that deviations from theological orthodoxy were not always the preserve of the peasant, nor indeed theological understanding the sole possession of the learned nobleman. The everyday practices typically associated with popular religion - a preoccupation with miracles and signs, the veneration of saints and their shrines, recourse to charms and amulets were indeed popular because they were common and widespread; and they certainly did not exclusively belong to the lower social orders. ${ }^{4}$

The fascination with relics, for instance, crossed all social barriers. It is ironic that the protector of Martin Luther, Elector Frederick the Wise of Saxony, possessed one of the most impressive relic collections, which was guaranteed to shorten Purgatory by 1,902,202 years and 270 days for visitors who paid to see them; these included a feather from the angel Gabriel, hay from Christ's manger, Christ's swaddling clothes, a wisp from Jesus' beard, bread from the last

(C) 2012 The Author. The Heythrop Journal (c) 2012 Trustees for Roman Catholic Purposes Registered. Published by Blackwell Publishing Ltd, 9600 Garsington Road, Oxford OX4 2DQ, UK and 350 Main Street, Malden, MA 02148, USA. 
supper, a branch of the burning bush, milk from the Blessed Virgin and one of the children killed by Herod in the massacre of the innocents. Frederick the Wise, it must be admitted, was no peasant. In 1599, closer to home, we find the learned Scots Jesuit James Gordon Huntley, who was a philosopher and theologian of note, in addition to being a Hebrew scholar, arriving in Ireland as apostolic nuncio. On arrival, he went on pilgrimage to the tomb of St Patrick in Down and took away some earth from the grave, which he found to have miraculous effects. ${ }^{5}$ The Jesuits, of course, were well disposed towards sacramentals, using agnus deis and Xavier and Ignatius water ${ }^{6}$ liberally in their missions. These were, however, 'respectable' sacramentals and although they worked in very much the same way as their antecedent and 'suspect' counterparts, they distinguished themselves by being part of legitimate Tridentine devotion.

All pilgrims engaged in relic collecting - rich, poor, noblemen and peasants. Felix Fabri, a fifteenth-century Dominican writer and pilgrim, attempted in his writings to distinguish between elite and popular pilgrims to Jerusalem, but while criticizing people (even nobles) who chip off bits of stone from the Holy Sepulchre to take home with them, he nevertheless inherited one of these relics from a dying pilgrim, which he duly kept. ${ }^{7}$ Fabri also records that there was a mania among the nobility for collecting holy innocents (as borne out by Elector Frederick of Saxony) and he alleges that the Saracens manufacture counterfeit 'innocents' from the bodies of unbaptised babies. ${ }^{8}$ So devotion to relics was certainly not confined to the peasant or the uneducated. A Carthusian monk, Hugh of Avalon, whom King Henry II of England had appointed as head of one of the monastic establishments which the King founded, went on to be elected as Bishop of Lincoln in 1186. His biographer would later describe in detail the bishop's passion for relics, of which he was an avid collector, in an account which is both vivid and illuminating. In one place his biographer describes how the bishop was visiting the Benedictine monastery of Fécamp in Normandy when he was told of the presence there of relics of Mary Magdalene in the form of two small fragments of bone. These had never been seen outside of their wrappings which consisted of three sewn cloths, two of silk and one of ordinary linen. When the bishop asked to see the relic the monks did not dare to unveil it; Hugh of Lincoln was not a patient man, though, especially when there was a relic to be seen, and so his biographer's account takes up the story:

He, however, taking a small knife from one of his notaries, hurriedly cut the thread and undid the wrappings. After reverently examining and kissing the much venerated bone he tried, unsuccessfully, to break it with his fingers, and then bit it first with his incisors and finally with his molars. By this means he broke off the two fragments which he handed immediately to the writer with the words, "Take charge of this for me with special care". When the abbot and the monks saw what had happened they were first overcome with horror, and then became exceedingly enraged. They cried out "What terrible profanity! We thought that the bishop had asked to see this holy and venerable relic for reasons of devotion and he has stuck his teeth into it and gnawed it as if he were a dog". But the bishop replied "If, a little while ago, I handled the most sacred body of the Lord of all the saints with my fingers, in spite of my unworthiness, and when I partook of it, touched it with my lips and teeth, why should I not venture to treat in the same way the bones of the saints for my protection, and by this commemoration of them, increase my reverence for them, and without profanity acquire them when I have the opportunity?"9

The relics of the Magdalene, like a plethora of other popular saintly figures, could be found in many different locations. Durham cathedral in the north of England, for instance, claimed to possess a crystal vial containing her hair and veil. A list of the relics held at Durham from 1373 included, among other items, a piece from the Lord's manger in a blue silk purse, a garment belonging to John the Baptist, a piece from the Virgin Mary's tomb and a piece of Veronica's 
handkerchief and some other less significant items such as a joint of St Lawrence, partly burned by fire, and a piece of St Barbara's skirt. ${ }^{10}$ In an Irish context, Tadhg Ó Cianáin's account of the travels of the Ulster earls on the Continent post-1607 also attests to the enduring fascination with relics and shrines, which the earls visit at every opportunity. ${ }^{11}$ In another well-known account, a Spanish captain, Francisco de Cuellar, who was shipwrecked off the Irish coast in 1588 , describes being robbed by a seventy-year-old 'savage' and his young female 'savage' companion, who took some relics of great value from him, which the female hung around her neck, indicating to him that she wanted to keep them and explaining that she was a Christian. ${ }^{12}$ The scandal here was not that the 'savage' craved relics (the Spanish captain obviously held these in high esteem, himself) but that she was prepared to steal them from him (then again, perhaps the Spanish captain had not heard of Bishop Hugh of Lincoln who had attempted his own relic heist in France many centuries before!)

Where a distinction can be drawn between the religion of the lower orders and the elites is not at the level of what was believed (for there is ample evidence to suggest that a shared belief system can often be found operating here) but rather in the access individuals and groups had, for instance, to instruments of devotion, i.e. the material objects of piety. It is unlikely that many peasants possessed a full 'holy innocent', for example, or, for that matter, as prized a possession as Christ's 'nappy'. What is certain, however, is that they would have very much liked to. Not everyone was able to afford to commission devotional miscellanies like the one compiled for a Donegal noblewoman, Máire Ní Mháille, wife of Ruaidhrí Mac Suibhne Fanad, in 1513. ${ }^{13}$ However, the religious ideas underpinning much of the content of devotional collections such as these were quite familiar. The merita missae text, which promised a plethora of benefits for those who attended Mass and viewed the Eucharistic host - everything from good digestion to good business, non-ageing to the forgiveness of venial sins (and which appeared in Máire's collection) - was not available to everyone in written format (and indeed, not everyone could read it). However, it is arguable that its basic content, or at least the thrust of the message, was familiar to large numbers of people who zealously exhibited a kind of merit mania in rushing from church to church to catch as many Eucharistic consecrations as possible. Over time, of course, possessions such as medieval Books of Hours in which a wide variety of devotional miscellanea appeared, moved steadily down-market, appearing in ever cheaper and more functional versions. ${ }^{14}$ The point here, then, is that one of the differences between elite and non-elite religion can be seen not in its basic content but in the forms in which it appeared.

In effect, the daily preoccupation of both the learned and unlearned, the literate and nonliterate, the peasant and the nobleman or woman was how to most successfully conduct business with the supernatural world. Doctrine is all very well, but what makes religion 'popular' is its usefulness, its practice and, essentially, its tangibility. ${ }^{15}$ In this sense, all social strata had to contend with common challenges of life such as sickness, death and the warding off of evil. How this business was conducted was always a concern for church authorities and the word superstitio or 'superstition' was used to describe false belief, paganism or magic but also superfluous and inappropriate practices. For early modern Protestant polemicists it was used as a type of shorthand for pre-Reformation Catholic practices. However, even churchmen were not sure where to draw the line between religion and superstition. ${ }^{16}$ The Tridentine church found itself in a complicated position, meanwhile; if it conceded too readily that the medieval church was riddled with superstition and magic it would provide ample fodder for Protestant propagandists and yet if it openly supported dubious practices it would subject reformed Catholicism to ridicule and undo much of the work of purification that it wished to implement. The catechetical literature from the Irish Franciscan foundation of St Anthony's College, Louvain, provides numerous examples of Irish Franciscan friars walking what was a very difficult 
tightrope between the two when setting about the dissemination of Tridentine material in seventeenth-century Ireland. ${ }^{17}$ An Ulster Franciscan, Aodh Mac Aingil, in his tract on penance written in 1618, while defending the use of sacramentals in many places, nevertheless states that it is preferable to join a spiritual confraternity than to possess an indulgenced medal, cross or crucifix. ${ }^{18}$ Sacramentals without the sacraments and cures without catechesis were simply not deemed to be good enough anymore. And yet when faced with the trials of life and the more important trial of death common to people of all social rank and occupation, sacramentals proved enduringly popular. In seventeenth-century Spain, for instance, the Scapular of Our Lady of Mount Carmel experienced a resurgence (this scapular had a soteriological function, of course, promising exemption from Hell and release from Purgatory on the first Saturday after one's death); its six-hundred page hagiographical companion, Flores del Carmelo (1678), detailed how popular this sacramental was across the social spectrum. ${ }^{19}$

Popular religion - the response of all strata of society to doctrine - and what that involved (often bargaining with God, Mary or the saints on a quid pro quo basis) addressed feelings of genuine need and came from the heart. This kind of religion was tangible and worked frequently with material objects which had religious significance, Bynum's 'holy matter'. ${ }^{20}$ It was, in essence, incarnational religion - embodying what was essentially ineffable and what belonged to the realm of mystery. ${ }^{21}$ Popular religion comprised heart rather than head religion and thus allowed individuals from all social groupings, both clerical and lay, to engage with their God and the heavenly court in a familiar way and in a manner that made sense to them. The quid pro quo approach of simple transactions between humans and God was the essence of the commerce of popular religion. It must be recalled that the most influential portraits of the saints in the medieval world (those of the thirteenth-century Golden Legend) were transmitted in this format by a learned archbishop of Genoa, Jacobus de Voragine. Sainthood, on the other hand, most often grew from grassroots cults rather than imposition from 'the top down'. In recent years, historians have increasingly admitted that devotional influences worked in two directions - not just from the top down but also from the bottom up. Feasts such as Corpus Christi, for instance, first arose as local cults which were subsequently adopted by clerics and finally became universally recognized. In the case of Corpus Christi, no less a figure than Thomas Aquinas then composed two Latin hymns in celebration of the new feast which, over time, became favorites among the wider population, from which the feast had originally sprung. In a similar manner, the church's official liturgy, often regarded as the antithesis to the kind of DIY rituals of the lower classes, cannot be regarded as a fixed reality, untouched by popular culture. Popular cults such as the Five Wounds of Christ eventually had their impact on the liturgy itself for which a Votive Mass of the Five Wounds was approved in the fourteenth century. The liturgy, then, was constantly in dynamic relationship with the surrounding culture and developed accordingly, incorporating into its rites forms drawn from individual, domestic and community piety. And yet the acceptance of devotional favourites was by no means guaranteed during this period. With regard to feasts of the Blessed Virgin Mary, for instance, the Purification of Mary and Mary's Assumption were prescribed for universal observance during the Carolingian period of the late eighth and ninth centuries, while later would-be feasts of Mary such as her spasimo or swooning were not (the spasimo of Mary shows a distraught Mary fainting on Calvary as she watches her Son suffer, a scene which was very common in late medieval art). The spasimo would be rejected by Pope Julius II in 1513 on the advice of a theologian, the future Cardinal Cajetan. $^{22}$

It is important to make some distinctions at this point. Doctrine might be described as 'official' religion. However, once it is promulgated and received, it loses, in a sense, its doctrinal 'purity', becoming nuanced in a variety of ways. Like a metal that, on meeting air, becomes 
'oxidized', so doctrine becomes 'popular' when it meets the realities of individual lives. Popular religion, it might be argued, comprises the difference between the content of faith and its reception and subsequent expression. Reception is never merely a passive act of acceptance of a given doctrine; rather, it is a dynamic and creative process which implies interpretation, criticism and enrichment. Doctrine usually undergoes a process of filtering through culture, communities and individuals before it is truly 'received'. We could, of course, go back a step further and speak about the composition of doctrine itself, which is also culturally-conditioned and the result of a long and complex process. However, the point is that there are often significant gaps to be found between established doctrine and its subsequent promulgation, reception and expression. In the early modern period, this was to become a particular problem for Protestants who, having dispensed with the doctrine of Purgatory, now had to explain what might be meant by post-Reformation apparitions or sightings of ghosts. Here there arose a conflict between what Protestants thought they knew about reality from their experiences (and those of others) and what their theology told them about the same reality. ${ }^{23}$ The term 'elite' religion refers most appropriately to what was not available to the greater majority of devout believers. Since the broad assumptions of medieval and early modern religion may well have been shared across the social divide, we are left with a distinction not so much in cargo but in the vehicles that were used to transport it. Certainly wealthier and more intellectual believers could afford lavish Books of Hours, more impressive relics and might recite longer and more involved or learned prayers, but the general shape of the religious language they spoke was essentially the same. Indeed, perhaps language is a useful metaphor to explain the distinction. Where the categories of elite and popular do exist (if at all) they do not comprise separate languages; the learned devotee might have had a larger and richer vocabulary to draw from (greater access to texts etc.) but when it came down to expressing, in a heart-felt way, his/her devotion or indeed his/her need for supernatural help, the simplest and most straightforward approach was often deemed the most effective.

In the preface to the third edition of his Via Media, John Henry Newman argues that the tendency of religion to blend into superstition should be regarded not as a corruption of the gospel but instead as a sign that the gospel has been authentically inculturated: a religious culture that does not produce elements of superstitious faith has not properly become embedded in society (I like to think of this in terms of the Irish father who, when asked about his 'perfect' but rather dull child's progress at school replies "I don't mean to complain - Johnny is extremely good - but I sometimes wish he'd get up to even a small bit of devilment!"). Considering the practice of an old Neapolitan woman who chatters away to a crucifix, Newman doubts if a nation really has the faith if it is free from all degrees of what is commonly labeled 'superstition'. He comes to the conclusion that 'we may surely concede a little superstition as not the worst of evils, if it be the price of making sure of faith' ${ }^{24}$ In a similar vein, the Jesuit theologian, George Tyrrell (1861-1909), considered that theology, in its language and formulation (particularly manifest in the neo-scholasticism of the time), was often far too remote from the devotional life of ordinary believers to be an effective stimulus to faith and considered the saints and not the theologians to be the real teachers of the Church. ${ }^{25}$

Both Newman and Tyrrell make important points here. Late medieval and early modern religion was full of incentives to attend Mass or to say this or that set of prayers. Many of the rewards offered were of a spiritual or quasi-spiritual nature. However, a great number of them were to be enjoyed in the here-and-now and some were unashamedly worldly e.g. the fact that one's business would prosper if one attended Mass. Congregations often had to be coaxed into fervor by rather dubious means. Having arrived at a point of religious zeal, it was hoped that habit would then take over and result, ultimately, in virtue. Similarly, congregations were 
dissuaded from immoral action by placing before them consequences which they might like to avoid. For instance, the seventeenth-century Irish priest-scholar, Geoffrey Keating in his monumental work Trí Bior-Ghaoithe an Bháis (Three Shafts of Death), written during the 1630s, outlines four consequences of adultery - poverty, the loss of a limb or other body part (he doesn't specify which!), death without repentance (by drowning, fire or in battle) and being deprived of progeny (perhaps linked to consequence number 2 !) ${ }^{26}$ If this line of thought is followed through, congregations would naturally be inclined to espouse virtue and renounce sin having reached the stage of attrition (fear of hell and a whole lot more beforehand) rather than contrition. This was not the ideal as far as Tridentine reform was concerned, but it was practical and effective and that went a long way in its defense.

So what can this cursory journey through history teach us? Firstly, it teaches us that theology and popular piety cannot be regarded as separate entities. One naturally flows into the other; and indeed, the flow is not always in one direction. It might be argued that religious experience in the early Church had a formative influence on the development of doctrine, most explicitly perhaps in the experience of Saul of Tarsus. As a pious Pharisee, Saul might have expected that the Messiah would be a righteous figure who would not die a death by crucifixion: a crucified/ cursed Messiah would, indeed, have been a contradiction in terms ${ }^{27}$ Yet of course Christ dies as a common criminal. However, what Luke Timothy Johnson calls the "cognitive dissonance ${ }^{28}$ of Paul's experience on the road to Damascus, in which he has a profound experience of the Risen crucified Christ, changes all of that and causes Paul to work backwards from his now unwavering conviction that Jesus has been raised from the dead and thus vindicated by God. Paul's theologizing, his attempt to work out what all of this means, leads him to the conclusion that Jesus did not die because of a lack of righteousness, but because he chose to die; his death becomes a sacrifice for the sins of others. And so, out of his experience on the road to Damascus he begins to 'preach Christ crucified, a stumbling block to the Jews and folly to the Greeks' as he puts it in 1 Corinthians 1:22-4. To view Christian doctrine as something that was 'sorted' from the beginning, therefore, is to ignore the evidence of the organic growth and development of doctrine within the lived experience of Christian communities. And as with every growth process, some things are adopted and others are shed. For instance, for the second-century Church Father, Irenaeus of Lyons' teaching of recapitulation (a reclaiming of all creation by Christ) to work as he intended, Irenaeus needed to hold that Jesus lived into his late forties and perhaps early fifties in order that he would experience all stages of human life (infant to child, to adolescent, to manhood, to middle age and then old age - around fifty), sanctifying each as he went along and reclaiming them for himself..$^{29}$ Irenaeus would argue vehemently from scriptural passages that Christ must have at least reached the age of a sage, and therefore that he did not die in his early thirties. While the concept of recapitulation would have a long future ahead of it in Christian thought, nevertheless later theology would not see the need to have Christ reach old age in order to redeem this particular stage of life. The idea of Christ as a fifty-year old would, on the whole, not survive in the popular religious imagination.

However, other concerns about age which arose at this time would have a lasting effect on the religious landscape, particularly of the West. I refer here to the putative age of Joseph, husband of Mary. In reading the gospels of Matthew and Luke, which provide us with birth and infancy accounts for Jesus, we get no indication whatsoever of the age of Joseph. Mary and Joseph might easily have been two teenagers. However, we are far more familiar from Western art, and also from our formative years, with Joseph as a much older man and Mary as a girl of about sixteen years of age. This particular image of the holy couple does not come from the gospels in the New Testament but, in fact, from a very influential apocryphal gospel, probably of the second century, the Protoevangelium Jacobi or 'Infancy Gospel of James' and its later and 
expanded Latin imitator 'The Gospel of Pseudo-Matthew'. ${ }^{30}$ This gospel fills many of the gaps left by the canonical gospels by taking the story backwards in time to the conception, not of Jesus, but of Mary herself to her parents Joachim and Anna (once again, most Catholics will be familiar with these names, but they won't have seen them in the New Testament because they are not found in any of the four gospels). The narrative relates how Mary grows up in the temple precinct and is dedicated to God as a virgin, but when she reaches the age of twelve the priests of the temple become eager to find a guardian for her, so they have all the older widowers of the locality line up to see who might be suitable. Joseph, one of the widowers, is holding a staff which miraculously brings forth a dove which settles on his head and thus he is selected to take care of Mary as his ward. Joseph's status as a widower will thus be used to account for Jesus' brothers in the canonical gospels: these are sons of Joseph from a previous marriage, and also, more crucially, his old age sends the message that he will be no threat to Mary's perpetual virginity, playing the role of protector rather than husband in the sense in which we would normally understand the term. And thus the concept of the elderly Joseph is born, which we are most familiar with. Christian iconography has been deeply influenced by the material in this gospel and this has reinforced and upheld the doctrine of Mary's virginity in the Catholic tradition. Incidentally, this is also where we find the statement that Mary was sixteen years of age when the angel visited her in the annunciation scene.

Theology is sometimes regarded as a party pooper, a big bad brother or sister that comes along when we are having a good time and tries to spoil our fun and to dispel our illusions. However, theology acts as an important corrective to popular piety which, if it becomes divorced from doctrine, and indeed from the life of the Christian community, can go astray. Just before Christmas of 2009, Church of England bishop of Croydon, Rt. Rev. Nick Baines caused a stir after media reports which detailed how he had criticized the lyrics of some of our best-known Christmas carols. One of the carols which attracted Baines' attention was Away in a manger. Of this carol, the bishop asked 'How can any adult sing this without embarrassment?', and went on in his book Why wish you a merry Christmas? to say:

I always find it a slightly bizarre sight when I see parents and grandparents at a nativity play singing Away in a Manger as if it actually related to reality. I can understand the little children being quite taken with the sort of baby of whom it can be said 'no crying he makes', but how can any adult sing this without embarrassment? I think there are two problems here: first, it is normal for babies to cry and there is probably something wrong if they don't; secondly, are we really to believe that a crying baby Jesus should be somehow theologically problematic? ${ }^{31}$

Despite attracting the ire of many who felt that, again, theological concerns were spoiling the pre-Christmas party, the bishop, of course, had a point, and a substantial one at that. In fact, it is not that a crying baby Jesus is theologically problematic, but rather, a non-crying baby Jesus is certainly so. In fact, like some other features of our Christmas card scene, the idea of "no crying he makes' in respect to the baby Jesus is supported by a Latin infancy gospel preserved in a fourteenth-century Latin nativity account known as Arundel MS 404, but which draws its material from much earlier infancy traditions. ${ }^{32}$ In this account we find the testimony of the midwife who comes to Mary's aid in the cave and this midwife reports of the child: 'he had no weight like other babies who are born ... I was amazed at him because he did not cry as newborn children are supposed to' ${ }^{33}$ Here, we find very strong echoes of a heresy that existed as early as the second century: docetism - the belief that Jesus did not possess a real human body, but just appeared to do so; the implication being that he was not fully human. This belief was particularly resisted by early Church Fathers because it denied the central tenet of the Christian faith: the Incarnation - God becoming man. For the baby Jesus to act abnormally and 
not to cry as normal babies do is to endanger the very heart of the Christmas event: the incarnation. Thus Bishop Baines' concerns about an embarrassing Christmas carol can be seen to be well-founded.

This is not to act as a carol-kill-joy but, rather, to highlight that the words we use have consequences for what we believe - and a half-hearted attempt at being a human baby on Jesus' part just won't do. Baines, also highlights a phrase in the carol 'Once in Royal David's city' which speaks of Jesus as 'our childhood's pattern', and that Christian children should all be 'mild, obedient, good as he'. Dismissing this as a particularly Victorian slant on things, he rightly highlights that all we hear of Christ's childhood from the gospels is the one incident at twelve years old when he is actually disobedient to his parents and goes walkabout in the temple! Baines might also have mentioned that there is a wider tradition of Christ's childhood in the apocryphal gospels, especially the Infancy Gospel of Thomas, and the child Jesus portrayed there would not be a suitable pattern for anyone: in this apocryphal work, Jesus routinely gets into trouble, striking his child opponents dead or shrivelling them up when they get on his nerves and Joseph also has occasion to give him a good clip around the ear. ${ }^{34}$ The substantive point here is that our words mean something when we pray and worship, and thus we need to be sure that they are the right words, conveying what we wish to convey about the essential truths of our faith. Theology can play an important role, then, in ensuring that we adhere to the 'Rule of Faith' as Irenaeus of Lyons called it. What we pray influences what we believe - as the Latin adage has it, 'Lex orandi, lex credendi'. This also goes for what we hear sung in our churches, or indeed what we sing ourselves. It has often been pointed out that the country singer Nanci Griffith's popular song, From a distance, which was at one point a popular hit in many churches, describes not the Christian God who became man and embraced fully and intimately human experience, becoming one like us, but rather the God of the Deists of the Enlightenment, who, having created the world, leaves it to its own devices and very much 'keeps his distance'. Words matter.

Our devotional lives, when lived apart from a faith community and the stability of liturgical and scriptural texts, can take quite different paths and the elements of a shared religious grammar can morph into something quite different from what they originally were. Divorced from their scriptural setting as God's messengers, for instance, angels can take on quite a different identity in the wider religious world. Nowadays, of course, there is a fascination with these beings; but today they are probably more likely to read you your horoscope while sitting on your shoulder than to act as heavenly messengers as they do in scripture, or indeed accompany you to church, as was frequently the case in pious stories in which angels were believed to enumerate one's steps along the way to Mass, each footstep earning a spiritual reward in heaven. Once angels come away from their packaging as messengers and ministers of God, who attend at the heavenly court and hover in adoration around the Eucharist, they don't necessarily have to be 'churched' at all, so to speak; they can more easily function as spiritual companions who have, like many mortals, dumped religion for spirituality. The distinction between angelic beings and humans has also tended to be blurred in popular culture - many people believe that becoming an angel is actually a reasonably attainable job prospect for all those who reach heaven. Once there, the human-cum-angel may then be redeployed to earth to do good deeds, just as Jonathan Smith was in the 1980s' TV series Highway to Heaven. ${ }^{35}$ Apart altogether from the merits or not of such TV programmes, such a categorisation of angels might very well attract the beady eye of theologians who point to the Christian teaching that angels are incorporeal spirits who are messengers and ministers of God, and not dead humans who have gained a promotion. However, increasingly, there is not such a fuss made about angels any more in mainstream Christianity - in part, this is because they are thought to have been hijacked by 
the New Agers but also because, for some, they are too often associated with the fastidiousness of scholastic theology ('How many angels can dance on the head of a pin?'). And yet by ignoring Christian teaching in areas such as these, however esoteric they might appear, theology risks vacating yet another of its fields, abandoning it to be occupied by all passers-by who may choose to cultivate the land with other crops, or indeed to leave it fallow altogether. This is another reason why theology should not abandon popular piety, nor become embarrassed by it when interrupted at a very important official function. Because if it looks down its nose at the vagaries of popular religious expression and sneers, wine glass in hand staring coke can in fist, 'Have we met before? I don't know you. Please leave me alone', then the result will be marginalisation. And what is marginalised is often radicalised. And the Christian Church has often learnt this lesson the hard way through the centuries.

\section{CONCLUSION}

In order for a fruitful relationship to exist between theology and popular piety, a healthy theology will always be prepared to recognise the lived reality of genuine religious expression, however messy that might appear to purists. It's important to state that I am not speaking here of deviant religious expression or of any kind of heterodoxy. Rather, I have in mind the ordinary lived expression of people's belief: the manner in which they kiss the cross at the end of their rosary beads, the particular manner in which they offer votive lights before their favourite saints; the way they might touch the foot of a statue of the Virgin Mary or St Joseph on leaving church; the leaving behind of various ex-votos as permanent reminders of a visit to a Marian grotto, and so on. These all constitute very powerful and deeply-held signs of personal belief. Perhaps the most moving experience I have had in many years was a visit in October 2009 to the Marian shrine of Altötting in Bavaria, a place that Pope Benedict XVI holds very dear. The small chapel which houses the Black Madonna is covered from top to bottom, both inside and out, with hundreds and hundreds of small paintings, ex votos, left by pilgrims to the shrine. Each of these depicts a different scene of whatever distress the pilgrims found themselves in at the time; each carries a date, and each carries the same refrain 'Maria hat geholfen' ('Mary helped') - the earliest of these simple paintings goes back to the late 1600s. They depict times of war, sickness and famine. Among the most poignant were those depicting bomber planes during the years of the Second World War, bombs being dropped indiscriminately on town streets, fires blazing and bodies scattered. 'For the time when the houses in our street were all destroyed and ours was saved . . Maria hat geholfen'; 'for my son who was spared during the 1914-18 war . . Maria hat geholfen'. There are also some more humorous depictions - one from the 1950s shows a Bavarian farmer lying under a small red tractor in a field with a caption which more or less ran 'For the day my little red tractor turned over on top of me ... Maria hat geholfen!'. Here was a living litany of praise, far more impressive than any formally composed litany could offer, the refrain echoing down the centuries the deep faith of Bavarian pilgrims ... 'Maria hat geholfen ... Maria hat geholfen'. The paintings continue to appear on the outer walls of the little church. In late 2009 'Maria hat geholfen' was still as deeply felt as ever.

I find it most helpful to define 'popular religion' as the reception and expression of doctrine by individuals and communities. It is, in effect, the practice of religion and belief - religion that is 'lived' and embodied. In the process of embodiment and expression, doctrine becomes inculturated and nuanced. This is a process that unfolds in the houses of the nobility as much as in the hovels of the poor, in both the halls of the educated and the hamlets of the unlearned. 
In this sense, all who receive and then put into effect religious doctrine have popularized it. Where it will go from there is anyone's guess. The most intellectual of receptors have carried it into so-called 'heresy' and the most lowly into canonized 'sainthood'. The possession of a library of theological works might suggest that its owner subscribes to the religion of the elite. However, unless that religion trades page for praxis, it can never become popular. And if it does not become popular, it dies.

\section{Notes}

1 An early version of this paper was presented at the Newman Institute, Ballina, County Mayo, on 9 February 2010.

2 Peter Burke, Popular culture in early modern Europe (New York: Harper and Row, 1978).

3 Martin Ingram, 'Ridings, rough music and the reform of popular culture', Past \& Present 105 (1984), 79-113; Eamon Duffy, The stripping of the altars (New Haven: Yale University Press, 1992). The scholarly output on this topic since Duffy's work is vast and it would be foolish to attempt a list of relevant titles here. A relatively recent volume of Studies in Church History is devoted to this very question: see Kate Cooper and Jeremy Gregory (eds), Popular and Elite Religion: Studies in Church History 42 (Woodbridge: Boydell and Brewer, 2006). More recently still, Euan Cameron's Enchanted Europe: superstition, reason and religion, 1250-1750 (Oxford: Oxford University Press, 2010) is also worthy of note.

4 For this argument in greater detail see Salvador Ryan, 'The most contentious of terms: towards a new understanding of late medieval "popular religion", , Irish Theological Quarterly 68:3 (2003).

5 Edmund Hogan, Distinguished Irishmen of the sixteenth century (London: Burns and Oates, 1894), pp 326-7. For a fascinating and very readable introduction to saints' relics in the Middle Ages see Charles Freeman, Holy Bones, Holy Dust: how relics shaped the history of medieval Europe (New Haven: Yale University Press, 2011).

6 This was water in which relics of Francis Xavier or Ignatius Loyola had been placed, thus imbuing it with miraculous properties. See Trevor Johnson, 'Blood, tears and Xavier-Water: Jesuit missionaries and popular religion in the eighteenth-century Upper Palatinate', in Robert Scribner and Trevor Johnson (eds), Popular religion in Germany and Central Europe, 1400-1800 (Basingstoke: Palgrave, 1996) 183-202.

7 Kathryne Beebe, 'Elite and popular experience of the Jerusalem pilgrimage', in Kate Cooper and Jeremy Gregory (eds.), Elite and Popular religion, 106.

8 Ibid.

9 'Bishop Hugh of Lincoln's devotion to relics (1186-1200)', in John Shinners (ed.), Medieval Popular Religion, 1000-1500: a Reader (Peterborough, Ontario: Broadview Press, 1999), 176-7.

10 'Relics at Durham cathedral (1383)', in Shinners (ed.), Medieval Popular Religion, 195-200.

11 Nollaig Ó Muraíle (ed.), Turas na dTaoiseach nUltach as Éirinn: from Ráth Maoláin to Rome: Tadhg Ó Cianáin's contemporary narrative of the journey into exile of the Ulster chieftains and their followers, 1607-8 (Rome: Pontifical Irish College, 2007).

12 The Spanish captain added '. . . which she was, in like manner as Mahomet'. See Francisco de Cuellar, 'Letter from one who sailed with the Spanish Armada and tells the story of the enterprise of England' (prepared by D. W. Cruickshank and P. Gallagher) in P. Gallagher and D.W. Cruickshank (eds), God's obvious design: papers for the Spanish Armada symposium, Sligo, 1988 (London: Tamesis Books, 1990), 232-3.

13 See Salvador Ryan, 'Windows on late medieval devotional practice: Máire Ní Mháille's "Book of Piety" (1513) and the world behind the texts', in Rachel Moss, Colmán Ó Clabaigh and Salvador Ryan (eds), Art and Devotion in late medieval Ireland (Dublin: Four Courts Press, 2006), 1-15.

14 See Eamon Duffy, Marking the hours: English people and their prayers, 1240-1570 (New Haven: Yale University Press, 2007).

15 Salvador Ryan, 'The quest for tangible religion: a view from the pews', The Furrow (July/August, 2004).

16 Helen Parish and William J. Naphy (eds), Religion and superstition in Reformation Europe (Manchester: Manchester University Press, 2002), 4. See the wider question treated in Cameron, Enchanted Europe.

17 Salvador Ryan, "New wine in old bottles": implementing Trent in early modern Ireland', in Thomas Herron and Michael Potterton (eds), Ireland in the Renaissance, c. 1540-1660 (Dublin: Four Courts Press, 2007), 122-37.

18 Aodh Mac Aingil, Scáthán Shacramuinte na hAithridhe, ed. Cainneach Ó Maonaigh (Dublin: Dublin Institute for Advanced Studies, 1952), 196. 
19 Trevor Johnson, "Everyone should be like the people": elite and popular religion and the CounterReformation', in Kate Cooper and Jeremy Gregory (eds.), Elite and Popular religion, 213. For some recent principles on the use of sacramentals see Congregation for Divine Worship and the Discipline of the Sacraments, Directory on Popular Piety and the Liturgy: Principles and Guidelines (London: CTS, 2002).

20 See Henning Laugerud and Laura Skinnebach (eds), Instruments of Devotion: the practices and objects of religious piety from the late Middle Ages to the 20th century (Aarhus: Aarhus University Press, 2007); Caroline Walker Bynum, Christian materiality: an essay on religion in late medieval Europe (New York: Zone Books, 2011).

21 Bynum recalls Jean-Claude Schmitt and André Vauchez's arguments that the late medieval attachment to physical objects was a 'logical working out' of the doctrine of the Incarnation. Christian materiality, 33.

22 Miri Rubin, Mother of God: a history of the Virgin Mary (New Haven: Yale University Press, 2009), 362.

23 See especially Peter Marshall, 'Deceptive appearances: ghosts and reformers in Elizabethan and Jacobean England', in Helen Parish and William J. Naphy (eds), Religion and superstition, 188-208.

24 John Henry Newman, Via Media of the Anglican Church ( $3^{\text {rd }}$ edition, London, 1877), xviii.

25 Clara Ginther, 'The relation of theology to devotion: an exploration of a central theme in Tyrrell's theology', in Oliver P. Rafferty (ed.), George Tyrrell and Catholic Modernism (Dublin: Four Courts Press, 2010), 105; Michael Hurley, 'George Tyrrell's ecumenical spirituality?' in Rafferty (ed.), George Tyrrell, 127.

26 Geoffrey Keating, Trí bior-ghaoithe an bháis: the three shafts of death, ed. Osborn Bergin, (Dublin: Royal Irish Academy, 1931), 170.

27 Deut 21:23. James D.G. Dunn, The theology of Paul the apostle (Grand Rapids: Eerdmans, 1998), 209.

28 Reading Romans: a literary and theological commentary (Macon, GA: Smyth and Helwys Publishing, 2008), 117.

29 Robert M. Grant, Irenaeus of Lyons (London and New York: Routledge, 1997), 33.

30 See Paul Foster, The non-canonical gospels (London: T\&T Clark, 2008), 110-25.

31 http://www.guardian.co.uk/world/blog/2009/nov/30/christmas-carols-bishop-criticism (accessed 13 September 2011).

32 Bart D. Ehrman and Zlatko Pleše, The apocryphal gospels: texts and translations (Oxford: Oxford University Press, 2011).

33 David R. Cartlidge and David L. Dungan (eds. and trans.), Documents for the study of the gospels (Philadelphia: Fortress Press, 1980), 105-6.

34 Tony Chartrand-Burke, 'The Infancy Gospel of Thomas', in Paul Foster (ed.), The non-canonical gospels, 126-38.

35 The series was both produced by and starred the late actor, Michael Landon, and ran for five seasons on NBC from 1984 to 1989. 